\title{
THE EFFECT OF PRICE DISCOUNT AND IN-STORE DISPLAY ON IMPULSE BUYING
}

\author{
Zulki Zulkifli Noor \\ Universitas Jayabaya, Jl. Pulomas Selatan Kav No.23 Kayu Putih, Kec. Pulo Gadung, Kota Jakarta Timur \\ E-mail: zulkizulkiflinoor@gmail.com
}

\begin{abstract}
This study aims to determine the effect on the Impulse Buying Discount Price on Borma Departement Store Bandung, determine the effect of In-Store Display on Borma Departement Store Impulse Buying in Bandung, and determine the influence of Price Discount and In-Store Display on Borma Departement Store Impulse Buying in Bandung. The methodology used is a descriptive quantitative method, the unit of analysis in this study is Borma Departement Store Terrain and observation units are customers of Borma Departement Store Terrain much as 980 respondents. Mechanical determination of the number of samples used in this study is the systematic randomsampling and the sample size is 91 respondents. The method used the techniques of collecting data through library research and field research conducted systematically based on objective research. The analytical method used to solve problems and prove the hypothesis is descriptive analysis. The finding are price discount has a positive and significant impact on the Impulse Buying.InStore Display partially has a positive and significant impact on the Impulse Buying.Price Discount and In-Store Display simultaneously have a positive influence on Impulse Buying..
\end{abstract}

Key words: Price Discount; In-Store Display; Impulse Buying

\section{PENGARUH POTONGAN HARGA DAN TAMPILAN DALAM TOKO TERHADAP PEMBELIAN IMPLUSIF}

\begin{abstract}
ABSTRAK. Penelitian ini bertujuan untuk mengetahui pengaruh potongan harga terhadap pembelian impulsif pada Borma Departement Storedi Bandung, mengetahui pengaruh tampilan dalam toko terhadap pembelian impulsif pada Borma Departement Storedi Bandung, dan mengetahui pengaruh potongan harga dan tampilan dalam toko terhadap pembelian impulsif pada Borma Departement Storedi Bandung. Metodologi penelitian yang digunakan adalah metode deskriptif kuantitatif, unit analisis dalam penelitian ini adalah Borma Departement Storedi Bandung serta unit observasinya adalah pelanggan dari Borma Departement Storedi Bandung sebanyak 980 responden. Teknik penentuan jumlah sampel yang digunakan dalam penelitian ini pengambilan sampel secara acak sistematis denganukuran sampel 91 responden. Metode penelitian yang digunakan yakni dengan teknik pengumpulan data melalui penelitian kepustakaan dan penelitian lapangan yang dilakukan secara sistematik berdasarkan tujuan penelitian. Metode analisis yang digunakan untuk memecahkan permasalahan dan membuktikan hipotesis adalah dengan analisis deskriptif, analisis regresi. Temuan penelitian ini adalah potongan harga berpengaruh positif dan signifikan terhadap pembelian impulsif di borma departement menyimpan. Tampilan dalam toko berpenagruh positif dan signifikan terhadap pembelian impulsif. Tampilan dalam toko dan potangan harga secara simultan memiliki pengaruh positif terhadap pembelian impulsif.
\end{abstract}

Kata kunci: Potongan Harga; Tampilan dalam Toko; Pembelian Impulsif

\section{INTRODUCTION}

The retail industry is one of the many leading industry that experiencing the development of quite positive. Association of indonesian retailers (Aprindo) predicts the country of the retail industry years 201 growing $12 \%$ to IDR 188,16 billion, compared with the credits provided the realization of last year which was around IDR 168 billion. The growth will be triggered by bi decision to indonesia economic development on is a good enough.

Based on the above data it can be seen that the growth of the turnover of the national retail loan was not. The turnover of modern retailers that is to achieve a century of 2014 year counter market was up only thin as much as $10 \%$ from the previous year specifically 9,6 $\%$ while it is estimated that will grow up into $12 \%$ in the year 2015. Demand fast moving of consumer goods (FMCG) of especially food and drink it is still a big a key contributor ( $>60 \%$ ) (Office of Chief Economist Bank Mandiri, 2018).
One of the retail industry that is in Indonesia that is the department stores. The department stores are a place shopping who it is becoming even by the consumer such interest has been expressed in. Thing was due to the fact the department stores would be able to deliver an excess of as the lightness of to their customers to choose goods preferred by the with a wide range of to choose from the price of, a brand, size and quality from products of a mount of money needed. Some department stores the exist in Indonesia and among the companies were such as PT. Matahari department stores, Ramayana shopping center department stores, Yogyakarta Bromo department stores, Borma department stores etc. For the rapid development of the department stores in Indonesia were encouraged by the fact business expansion the sun the department stores and of Ramayana shopping center department stores the controlling approximately $55 \%$ of the market segment of (Office of Chief Economist Bank Mandiri, 2018). The large number of publicly listed retail company especially the department stores has caused consumers income to the difficulties they face in great searching of heart for selecting villagers to the department stores. 
A few rules the government about the existence of the retail industry in Indonesia, such as the president of the republic of Indonesia number 112 years 2007 concerning the arrangement and coaching, traditional markets shopping centers and modern shops as well as the ministerial decree industry and trade the republic of Indonesia no 107 / MPP / cap / 2 / 1998 about provisions and procedures for granting. modern market business.

The development of retail industry in Indonesia means that each company to able to survive and compete in the market. Now retailers compete to us consumer to want to shopping in its place, as by administering discount, door prize etc. It was aimed to attract attention consumers although retailers must spend money which is large. Various ways offered by retailers to ease consumers to elect place shopping to suit the needs and their desire, so it will give rise to interest in buying consumers.

The consumer will be interest in buying with itself if consumers already feel are interested in what is offered by the seller. Consumers interest in buying is the tendency to buy a brand or take action that deals with the purchase of measured by a degree possible consumers do purchases in online stores (Bala \& Deepak Verma, 2018). The size of the interest of consumers on a product can increase consumer interest in buying.

Interest on the consumer will be a decision was to provide the basis. A positive buying interest will encourage consumers to make the purchases and interest buy negative will hold consumers not to buy. Competition is very competitive in department stores own impact on sales volume especially in the Borma department stores. As happened in 2018, sales volume in the Borma department store tends to climb down every month.

The sales volume in the Borma department store in 2018 experienced fluctuating. A decrease that the sharpest happened in September which can sold as many as 94,94 $\%$. This condition is one of the impact of the increasing number of competitors of department store yourself so that affect interest in buying consumers to choose buy to another. A lot of factors affect the decline in the sale, one of a contributing factor among them were pertaining to of the Borma department store who is now decline. Interest in buying types of buyers in the Borma department store seems a handful less, and influential to a decrease in sales. This proves that inappropriate marketing strategies made by the company, and avoid interest in buying on the consumer and the purpose of company will not be achieved.

One strategy can be done by a company to competition ahead and build and maintain the image of store and form an image of positive consumers mind. Positive image store not only useful to attract consumers from to buy it, company or products but also in improving the consumers over organisation. Store will reflect all image or personality to their customers. With other, the same shop perhaps reflects a different for the different customers
(Bala \& Deepak Verma, 2018). Construct and maintain good image has been critical performed by a retailers, as by positive image can affect consumer interest buy. Image are a set of belief, idea, a owned by someone toward an object (Frías Jamilena, Polo Peña, \& Rodríguez Molina, 2017) during, and after their stay.

But as the more competitors popping up both in the country and overseas who have explore market that is, make the image of the Borma department stores being declined. The decline because products offered by the Borma department stores less consistent with consumer expectations and capable of arousing interest consumers low purchasing.

This were felt the image at interest buy those who has also decreased. By the absence of buy company interest so the purpose would not be achieved and enterprise not to gain. When consumers have apprehends the department stores that the Borma having a poor, when consumers will fashion have need of consumers will not buy products at the Borma department stores but chose to buy elsewhere. It is a phenomenon that makes the Borma department stores ca not stay at competitive market as hyper competition perception of the if consumers are not fixed.

Judging from the growing number of consumers who follow the fashion trends are always evolving all the time, resulting in the fashion field of business competition is getting tougher. Most businesses are competing for business opportunities in the form of fashion sales. Fashion in this discussion is not just a style of dress but also accessories, makeup, and bags. As a business, to win business competition requires a different understanding of changing consumer behavior. Primarily, the company should be able to appeal to increase consumer interest in buying. Consumer purchases if viewed in terms of planning, categorized into purchases planned and unplanned purchases. The phenomenon that is much happening now is the consumer who originally only intended to accompany friends or family around and see the products displayed in a fashion store, accidentally saw a product that appeals to consumers spontaneously buy it. As for consumers who just want to buy a particular product, but when the product towards consumers passes some striking product display so interested in it, either because of rebates or remembering to buy the product.

Price Discount or rebate is a reduction in price from the list price set by the business in a given period. In setting the price cuts, to be sure businesses have to have a strategy for discounts given not to cause harm and can attract visitors, shoppers and those just passing by. In-Store Display or a product structuring indoor product planning activities to influence potential consumers to buy the products sold. Structuring the product must be considered, ranging from the arrangement based on the type, color, brand and with a strategic location, to give rise to potential consumers' desire to buy. Impulse Buying or unplanned purchases is a decision to buy a product without 
prior planning or occur suddenly. To increase unplanned purchases will require appropriate strategies, one of which is to give a discount on the product and is given a striking marker. Also, there should be a display of a product that is easily seen and accessible by prospective customers.

\section{Conceptual Framework}

According to (Utami, 2014), impulse purchases (Impulse Buying) are purchases that occur when consumers see a product or a particular brand, then consumers become interested to get it, usually due to the stimulation of interest from the store, and according to (Utami, 2014), there are four indicators Impulse Buying, among others: 1) Spontaneity (spontaneous), 2) power, compulsion, and intensity (strength, compulsions, and intensity), 3) excitement and simulation (excitement and simulation) 4) Disregard for consequences (indifference to the result). According (Wieseke et al., 2014) Price Discount is a reduction in the price of a product of the normal price in a certain period, and according to (Eeckhoudt et al., 2019), there are three indicator Price Discount, among other things: 1) The number of rebates, 2) The period of price cuts, 3 ) type of product get a rebate.

According to, (Bala \& Deepak Verma, 2018) InStore Display is an attempt to encourage the attention and interest of consumers at the store or to encourage the desire to buy through the appeal of direct vision, and by (Goldsmith, 2007), there are three indicators of In-Store Display, among others: 1) Product Supplying (Procurement), 2) Product Grouping (Grouping items), 3) Product Arranging (Preparation of Goods).

The following research hypothesis testing:

$\mathrm{H} 1$ : There is a positive and significant impact of discount Price on the Impulse Buying

$\mathrm{H} 2$ : There is a positive and significant effect of In-Store Display on Impulse Buying

H3: There is a positive and significant impact Price Discount and In-Store Display on Impulse Buying

The theoretical framework of this research will explain the relationship between each variable that can be seen in Figure 1.

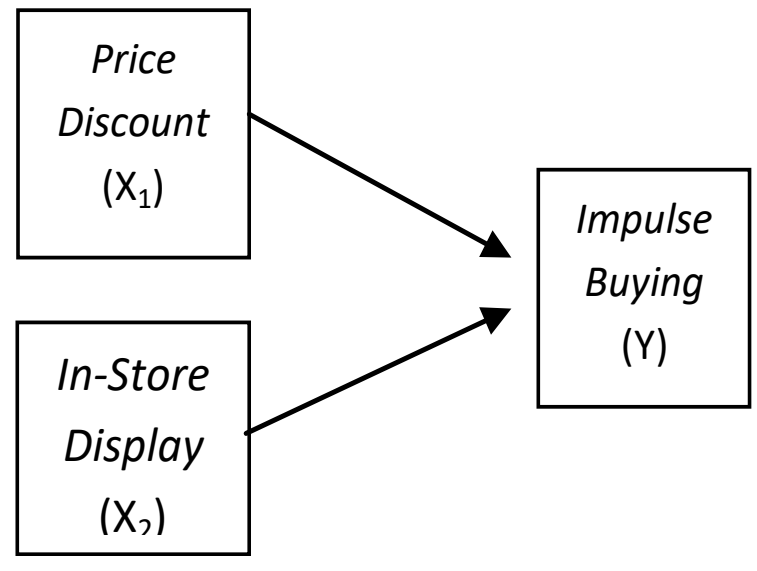

Figure 1. Research Paradigm

\section{METHOD}

The research was conducted on Borma Departement Store is located at Jl. Cikutra Bandung.The population in this study are all consumers who make purchases in-store. The total population is 980 people per year in 2019. The sampling technique using the systematic random sampling in this study. Thus, the samples size of this study is 91 respondents.

Data collection methods used in this study is a questionnaire (structured questionnaire) were given to the respondents, namely customers on Borma Departement Store. Conducted by researchers to obtain data that is by distributing questionnaires. The questionnaire method according to (Sugiono P.D, 2014) is a technique of data collection is done by giving a set of questions or a written statement to the respondent to answer.

This study, multiple linear regression analysis techniques used. Linear regression analysis related to the study of dependence The dependent variable (bound) with the independent variable (free), to estimate and predict the population mean or average value of the dependent variable based on an independent value known. Multiple linear analysis is used to determine the effect of Price Discount (X1) and In-Store Display (X2) on the Impulse Buying (Y).

\section{RESULTS AND DISCUSSION}

Before results result, esplanation about retail. Retail can be defined all the actions involved in selling the products directly to consumers the end for use in private and not used to do business (Utami, 2014). Retail also is an attempt to increase the value of good against a product or service sales to consumers. Many people define that retail is to sell products in the store, while not only that the services also included in. Retail activities include the sale of products that, form of goods, services and both. both to consumers. Working to find retail conformity of products sold with the its consumers. In addition, retail also facilitate the manufacturer to channel their products to consumers.

Characteristics of respondents by sex ie male respondents amounted to 28 people $(30.8 \%)$ and respondents Women numbered 63 people $(69.2 \%)$. It can be concluded that overall more dominant female respondents than male respondents. Characteristics of respondents by age that respondents aged $<21$ years amounted to $37(40.7 \%)$, respondents aged 21-30 years amounted to $32(35.2 \%)$ and respondents aged $31-40$ years were 22 people $(24.2 \%)$ ). It is explained that the whole age of respondents was 21-30 years because it has a higher percentage.

\section{Validity and Test The reliability}

According to Ghozali (2018), measure the validity can be done by performing the correlation between the 
scores of the questions with a total score of constructs or variables. The use of items as indicators of the variable data research requires an examination of consistency through the reliability test so that the data used is trustworthy or meet the reliability aspects for further analysis.

From validity test, $r$ values obtained a count of each item for each variable statement obtained above 0,361 so it can be said that the statement used in the study variables is said to validity.

From reliability test result, was also obtained from each of the variables in the Cronbach's Alpha is not below 0.6 so it can be expressed reliably. The cumulative distribution of the normal distribution.

\section{Classic assumption test Normality test}

The normality test aims to test whether the regression model or residual confounding variables have a normal distribution. There are two ways to detect whether or not a residual normal distribution, by analysis of graphs and statistical tests.

From normality test it can be seen that the data spread diagonal line and follow the direction of the diagonal line indicates a normal distribution pattern, the regression model is considered to meet the assumptions of normality. The data (point) spread around the normal line and follow the direction of the diagonal line or Normal Probability Plot a graph showing a normal distribution pattern.

Based on normality test result, it can be seen as a significant value greater than 0.05 is equal to 0.361 . These test results show that the normal distribution of data.

\section{Test of Multicollinearity}

The tolerance known value obtained was 0.823 more than 0.10 and the VIF value obtained was 1.215 which is less than 10 , so it can not happen otherwise multicollinearity problems with other independent variables.

\section{Heteroskidastity Test}

Based on Heteroskidastity Test, dots randomly or do not form a particular pattern that is spread both above and below the number 0 on the axis Studentized Regression Residual (Y). This means that not happen heteroskedasticity the regression model so it's a good regression model that was used to predict Impulse Buying.

\section{Results of Multiple Linear Regression Analysis}

\section{Table 1. Standardized Coefficients}

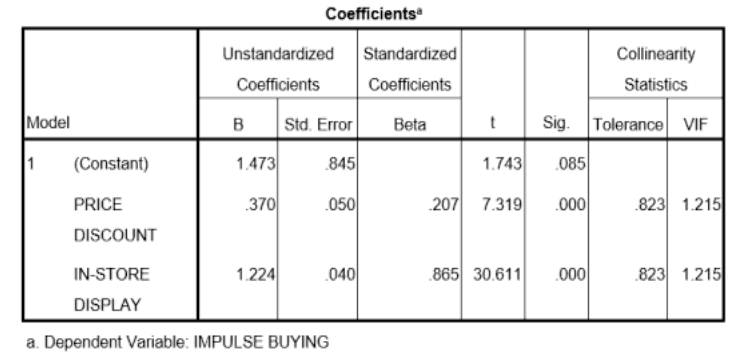

From table 1, testregression obtained multiple linear regression equation is: Impulse Buying $=1.473+$ $0.370+1.224$ Price Discount In-Store Display $+\mathrm{e}$

Explanation of the following equation:

1. 1,473 means: if the Impulse Buying studied constant, then the Impulse Buying on Borma Departement Store amounted to 1,473 .

2. Price Discount 0.370 indicates that the positive effect on increasing Impulse Buying at .370, so every one unit increase in the Discount Price, then the Impulse Buying will increase by 0.370 .

3. 1.224 indicates that the In-Store Display positive effect on Impulse Buying increased by 1,224, so every increase in the In-Store Display one unit, then the Impulse Buying will increase by 1,224.

The results of this study state the influence of Price Discount (X1) and In-Store Display (X2) on the Impulse Buying (Y) is shown from the results of multiple linear regression analysis Impulse Buying $=1.473+0.370+$ 1.224 Price Discount In-Store Display + e. This gives the sense that the variable Price Discount and In-Store Display simultaneous have a positive influence on Impulse Buying.

The result result above in line with premelinary research from(Utami, 2014) impulse buying is the purchase of what happens when consumers see the product or a particular brand, then consumers became attracted to get it, usually due to the motivate who withdraws from the store. According to (Park, Kim, Funches, \& Foxx, 2012) impulse buying is a purchase that made by consumers without being intentionally planned before which means shopping impulsive is a its purchase consumers without planned beforehand.

Impulse buying often occurs in retail goods low involvement as convenience. But when this impulse buying can also happen to goods who are too expensive for the middle class for. One example is in areas like, goods fashion especially of clothes (Mulyanegara, Tsarenko, \& Anderson, 2009).Impulse buying is behavior that is practiced accidentally and most likely involving various motives not realized that, and accompanied by a response strong emotional.

Behavior the purchase impulse having all the different levels to everyone. But all depends on these individuals, if she can control in the buying an impulsive or not .Impulse buying is something that drives prospective customers to act because of the pull over sentiment or passion certain .Attractiveness here pertaining to display goods compelling that someone hope to do a buyout. The purchase not planned is a the act of purchasing made without planned beforehand, or decision the purchase done at the time when be in the (Utami, 2014).

The purchase of impulsive usually occurs, when consumers have strong motivation that turns into a desire to buy products directly (Cohen, Prayag, \& Moital, 2014). Decision making consumers is a process of integrating that 
combined knowledge to evaluate two or more cognitive behavioral therapy and choose one of them.

Based on some definition of above we can conclude that the decision to buy the consumer is an election process one of several alternative resolution of problems were collected by a consumer, and create with further action that real . According to (Park et al., 2012) impulsive behavior is a behavior is done in fast, feel the (Sulaiman, 2010) pleasure that complex in which the speed of the process a decision blocking a consideration, impulses there was information, and to choose from.

From consumer side, of development of information technologies modern society has spur behavior consumers the consumptive coupled with progress banking system issued the credit card, debit card and others, so consumers especially the flipping took a turn for the hedonistic and impulsively (Rochdiani \& Nurul Utami, 2009). Consumers who impulsive is a segments its own market for hypermarket so that it can be deal specifically in order to increase performance store sales.

Level impulsivity consumers can be influenced by the iconoclasts and lifestyle families (Peschel, Grebitus, Steiner, \& Veeman, 2016) also can be influenced by a factor of demographic consumers that variative, as factors age , gender, education background, the family income, and composition family. The development of fashion and a positive emotion have the effect of behavior impulse buying.

According to (Alyas, 2017) positive emotions individuals affected by a mood that was already felt before, coupled with a reaction to the environment in that store, for example goods desirable and sales that were visited). A mood that positive will be more conducive to. Impulse buying happens when consumers are having a boost and demands of a sudden, strong and persistent to buy some things soon. A strong impulse, sometime unbearable or difficult to stop, a tendency to act and without deliberation.

T-test results showed that a partial Price Discount has a positive and significant impact on the Impulse Buying on Borma Departement Store for tcount amounted to 7.319 greater than the value of which amounted to 1.986 ttable.

The result result shows that price the discount is a promotion to attract the attention consumers to push desire candidates consumers in order to buy products offered. Inline with (Hayati \& Purnama, 2016), price the discount is discounts given by the seller to the buyer in recognition a certain activity of buyers who fun for the seller.

The consumers willing to seek well worth. Well worth means value in perception deserve at the time of the transaction was done .Inline with(Matsa, 2011) price the discount is discounts given by the seller to the buyer in recognition a certain activity of buyers who fun for the seller kind of price the discount there are four different discount, namely discount quantity, discount seasonal, discount cash, and trade the discount.Shopping with a price discount very easily be found in Indonesia because discount is one of the promotional strategy.
A discount seeming to be the main attraction to lure people to consume a goods. There are some understanding about a discount and discounts as suggested by some experts. According to (Wieseke, Alavi, \& Habel, 2014) discount is a reduction directly from the price of goods on the purchase during a period of time expressed. According to (Eeckhoudt, Gollier, \& Schlesinger, 2019)discount a chunk of the price offered by the seller to buyers in recognition of a certain activity from the buyer the delight of the seller. Based on some definition of above can be concluded that a discount is a reduction in the price offered by the seller to attract more consumers buy a product in a time period that has been determined.

The results of the t-test showed that the In-Store Display partially has a positive and significant impact on the Impulse Buying on Borma Departement Store for $t$ value of 30.611 is greater than the value of which amounted to 1.986 ttable.

The result shows that product displays is the way which is being undertaken to attract attention customers via the senses of sight. The management of the products used as a way in a shop to be able to attract the interest of consumers by looking at directly, this is the way stores in display or layout of merchandise to attract the interest of consumers to buy. Is to look at merchandise directly the consumer will be easily choose which type of goods needed, because of display distinguished in accordance with the type of goods. The implementation of an effective display in the atmosphere of a shop to look comfortable and interesting.

(Handayani sri, fariyanti anna, 2016) said that display was an attempt to build a goods which aims to steer buyers so that interested to see and buy. Display was a push attention and interest buyers in stores or goods and pushing the desire to buy one attraction a direct visual (Rochdiani \& Nurul Utami, 2009). Based on the pitch up so the displays in hotchpotch marketing promotion are categorized as sales promotion.

Store shopping environment/ shopping environment that is a shopping environment that the mood of consumers and emotion that can change the mood change so as to affect the purchase behavior of consumers. According to (El-Adly \& Eid, 2016)customer perceived value, customer satisfaction, and customer loyalty in regard to malls in the United Arab Emirates (UAE shopping environment is a form of marketing strategy service that can be used to give more values to consumers through experience in a shopping experience. Shopping environment through elements came as music, scent, the temperature, image, furniture, the style of service, and one can affect the psychological state of consumers through perceived enjoyment. And in-store shopping environment is the atmosphere of an environment expenditure on store that is deliberately created for shopping lessons can affect the purchase behavior.(Matsa, 2011) divide store environment into three parts, image, the store store 
atmosphere, theatrics and store. The store atmosphere is regarded as wrong one thing counts due to comfort while shopping in the consumer. According to (Zablah, Carlson, Todd Donavan, Maxham, \& Brown, 2016)the relationship between customer satisfaction and frontline employee (FLE the store are a combination of the atmosphere of the physical characteristics store, as architecture, the layout, with, display, color, lighting, temperature, music, and a thoroughly will create in mind customer image. They divide store atmosphere a shop into two, in store atmosphere covering the internal layouts, sound, smell, texture, interior design and store out atmosphere you covering external layouts, texture, and design exterior.

According to gilbert, store atmosphere is change made on design from the emotional buy that produce effects special then increase the likelihood of sense that purchases will last from above it can be concluded that the atmosphere in a shop physical environmental store is the description, through visual communication lighting, color, music, scent where consumers can stimulates perception and emotions so can influence the decision. Hence, retailers environment should be able to manage in a shop in such a way that increase the customers, in, the and stimulates a positive image of customers can be reached. Through the atmosphere store that is deliberately created, retail businesses to to communicate information related to the, price, merchandise where the goods to facilitate consumers from search and discover needs.

F test results indicate that the Price Discount and In-Store Display simultaneously influence the Impulse Buying on Borma Departement Store for $\mathrm{F}$ value 716.497 value greater than that of $3.10 \mathrm{~F}$ table.

The result of the coefficient of determination (R2) shows that the value of R Square obtained was 0.942 , which means $94.20 \%$ variable is affected by the variable Impulse Buying Price Discount and In-Store Display, while the remaining $5.80 \%$ is influenced by other variables that not examined in this study.

This research result in line with (Utami, 2014) impulse purchases (Impulse Buying) are purchases that occur when consumers see a product or a particular brand, then consumers become interested to get it, usually due to the stimulation of interest from the store, and according to (Utami, 2014), there are four indicators Impulse Buying, among others: 1) Spontaneity (spontaneous), 2) power, compulsion, and intensity (strength, compulsions, and intensity), 3) excitement and simulation (excitement and simulation) 4) Disregard for consequences ( indifference to the result). According (Eeckhoudt et al., 2019) Price Discount is a reduction in the price of a product of the normal price in a certain period, and according to (Wieseke et al., 2014), there are three indicator Price Discount, among other things: 1) The number of rebates, 2) The period of price cuts, 3 ) type of product get a rebate.

The same is also true in line with the results of the study (Bala \& Verma, 2018), In-Store Display is an attempt to encourage the attention and interest of consumers at the store or to encourage the desire to buy through the appeal of direct vision, and by (Goldsmith, 2007), there are three indicators of In-Store Display, among others: 1) Product Supplying (Procurement), 2) Product Grouping (Grouping items), 3) Product Arranging (Preparation of Goods).

\section{CONCLUSION}

The conclusion of this study arePrice Discount has a positive and significant impact on the Impulse Buying on Borma Departement Store. If borma department store, enacting the price discount then consumers will buy products without thinking first.In-Store Display partially has a positive and significant impact on the Impulse Buying on Borma Departement Store. If borma department store design store display an interesting and easily seen by consumers, then consumers will buy these products architect.Price Discount and In-Store Display simultaneously have a positive influence on Impulse Buying.However if seen in partial. So store display a dominant influence impulses buying than price discount. And consumers to be more see store display than price discount in unwittingly they buy.

\section{REFERENCES}

Alyas, (2017). Strategi Pengembangan Usaha Kecil Dan Menengah Dalam Penguatan Ekonomi Kerakyatan (Studi Kasus pada Usaha Roti Maros di Kabupaten Maros). Sosiohumaniora. 19,(2), 114 - 120. https:// doi.org/10.24198/sosiohumaniora.v19i2.12249

Bala, M. \& Deepak Verma, M. (2018). A Critical Review of Digital Marketing Paper Type:-Review and Viewpoint. International Journal of Management. 30, (2), 21-27.

Bala, M., \& Verma, D. (2018). A Critical Review of Digital Marketing . International Journal of Management. 3, (32), 1-22.

Cohen, S. A., Prayag, G. \& Moital, M. (2014). Consumer behaviour in tourism: Concepts, influences and opportunities. Current Issues in Tourism. 7(11), 23-32. https://doi.org/10.1080/13683500.2013.85 0064 .

Eeckhoudt, L., Gollier, C. \& Schlesinger, H. (2019). Asset Pricing. In Economic and Financial Decisions under Risk. 4(2), 15-24. https://doi.org/10.2307/j,

El-Adly, M.I., \& Eid, R. (2016). An empirical study of the relationship between shopping environment, customer perceived value, satisfaction, and loyalty in the UAE malls context. Journal of Retailing and Consumer Services, 31, (12), 217-227. https://doi. org/10.1016/j.jretconser.2016.04.002 
Frías Jamilena, D.M., Polo Peña, A.I. \& Rodríguez Molina, M.Á. (2017). The Effect of Value-Creation on Consumer-Based Destination Brand Equity. Journal of Travel Research. 5, (1), 9-17. https:// doi.org/10.1177/0047287516663650.

Goldsmith, J. (2007). Who Controls the Internet? Illusions of a Borderless World. Strategic Direction. 25, (2), 7-15. https://doi.org/10.1108/ sd.2007.05623kae.001.

Handayani S., Fariyanti, A. \& Rita. N. (2016). Simulation of analysis forecastfor beef self sufficient in indonesia. Sosiohumaniora. 18, (1), 61 - 70

Hayati, N. \& Purnama, R. (2016). Effect of the political marketing mix on the voter's decision (study on the Legislative Council Election of Representatives of the Republic of Indonesia Year 2014 constituency II West Java). International Journal of Applied Business and Economic Research.23(5), 21-32.

Matsa, D.A. (2011). Competition and product quality in the supermarket industry. Quarterly Journal of Economics, 126, (3), 1539-1591. https://doi. org/10.1093/qje/qjr031

Mulyanegara, R.C., Tsarenko, Y. \& Anderson, A. (2009). The Big Five and brand personality: Investigating the impact of consumer personality on preferences towards particular brand personality. Journal of Brand Management. 21(7), 61-72. https://doi. org/10.1057/palgrave.bm.2550093.

Office of Chief Economist Bank Mandiri. (2018). Menghadapi Era RI 4.0. 31, 217-227. Daily Economic and Market Review.

Park, E. J., Kim, E. Y., Funches, V. M., \& Foxx, W. (2012). Apparel product attributes, web browsing, and e-impulse buying on shopping websites. Journal of Business Research, 65, (11), 1583-1589. https:// doi.org/10.1016/j.jbusres.2011.02.043
Peschel, A.O., Grebitus, C., Steiner, B., \& Veeman, M. (2016). How does consumer knowledge affect environmentally sustainable choices? Evidence from a cross-country latent class analysis of food labels. Appetite. 02, (16), 23-35. https://doi. org/10.1016/j.appet.

Rochdiani, D. \& Utami, N.H. (2009). Peningkatan Pemasaran Susu Kedelai Bubuk Melalui Strategi Bauran: Studi Kasus Pada Pabrik Susu Kedelai Kadungora di Desa Kadungora, Kecamatan Kadungora, Kabupaten Garut. Sosiohumaniora. 11, (2), 140-153. https://doi.org/10.24198/ sosiohumaniora.v11i2.5415

Sugiono P.D. (2014). Metode penelitian pendidikan pendekatan kuantitatif.pdf. Metode Penelitian Pendidikan Pendekatan Kuantitatif, Kualitatif Jakarta: Dan R\&D.

Sulaiman, A.I. (2010). Realitas Politikus Perempuan sebagai Komunikator Politik. MIMBAR, Jurnal Sosial Dan Pembangunan. 2, (6), 221-232. https:// doi.org/10.29313/mimbar.v2.6i1.292.

Utami, H.D. (2014). Consumer Behavior Toward Goat Milk and Its Processed Products in Malang, Indonesia. Journal of International Food and Agribusiness Marketing. 53, (8), 78-89. https:// doi.org/10.1080/08974438.2012.755724

Wieseke, J., Alavi, S., \& Habel, J. (2014). Willing to pay more, eager to pay less: The role of customer loyalty in price negotiations. Journal of Marketing. 25(1), 23-33. https://doi.org/10.1509/jm.13.0104.

Zablah, A.R., Carlson, B.D., Donavan, T.D., Maxham, J.G., \& Brown, T.J. (2016). A cross-lagged test of the association between customer satisfaction and employee job satisfaction in a relational context. Journal of Applied Psychology, 101, (5), 743-755. https://doi.org/10.1037/ap10000079 